\title{
Positive conflict resolution behaviors in psychological health: Northern Cyprus sample
}

\author{
İsmail Hatun ${ }^{1}$, Nergüz Bulut Serin ${ }^{2}$ \\ ${ }^{1}$ Ministry of National Education, Hatay, Turkey \\ ${ }^{2}$ Department of Guidance and Psychological Counseling, Dr Fazıl Küçük Faculty of Education, European University of \\ Lefke, Northern Cyprus, Turkey
}

\begin{tabular}{l} 
Article Info \\
\hline Article history: \\
Received Apr 30, 2021 \\
Revised Aug 5, 2021 \\
Accepted Aug 26, 2021 \\
\hline
\end{tabular}

\section{Keywords:}

Conflict

Conflict resolution strategies

Secondary school students

Psychological health

\begin{abstract}
Conflicts are an inevitable part of school life, as in all areas of life, and minimizing the negative effects of conflicts and trying to develop constructive conflict resolution skills will positively contribute to human relations and mental health. The aimed of this study was to investigate the conflict resolution behaviors of secondary school students in terms of some psycho-social variables. The sample of the study was $6^{\text {th }}, 7^{\text {th }}$ and $8^{\text {th }}$ grade students attending the state secondary schools of the Turkish Republic of Northern Cyprus. The study was conducted with a total of 175 students of the students. The research was a descriptive study which is prepared by using quantitative research method which examines conflict resolution behaviors of secondary school students. The sample of the study was determined by nonrandom sampling method. In order to collect data, Conflict Resolution Behavior Determination Scale was used. In the analysis of the data; percentages, one-way analysis of variance (ANOVA), t-tests were used. As a result of the study, there was no significant difference according to the gender and grade level of the students. A significant difference was found according to their age, parental partnership status and success levels.
\end{abstract}

This is an open access article under the CC BY-SA license.

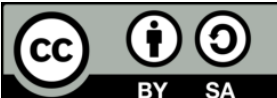

\section{Corresponding Author:}

Nergüz Bulut Serin

Department of Guidance and Psychological Counseling

European University of Lefke

Lefke, Northern Cyprus TR-10 Mersin, Turkey

Email: nserin@eul.edu.tr

\section{INTRODUCTION}

Early adolescents who reported using more collaborative and less aggressive conflict resolution strategies were reported to have less personal health risk behaviors [1]. Studies show that young people have difficulty coping with conflicts due to inadequate emotional regulation or their inability to perceive the consequences of their actions [2]. Considering that aggression and violence seen in schools can negatively affect both education and training effectiveness and the mental health of the individual, preventive studies are important for students to develop positive conflict resolution behaviors [3]. School life is essential for students to acquire basic life skills. Thus, when students resolve conflicts with their own skills, they also take responsibility for their actions [4]. Interpersonal violence in schools not only prevents teaching and learning, but also causes absenteeism and students' feelings of fear [5]. While conflict is an inevitable component of interpersonal relationships, without proper conflict resolution skills, school students can experience social isolation and academic decline [6]. 
Conflict between students is a common problem in schools. If they are not controlled, it has negative effects on the school climate [7]. Conflicts contribute positively to the development of children, it is important to develop social and emotional abilities in childhood, middle childhood and adolescence [8]. Koruklu [9] stated that in order for children to complete development of their desired, they should be given conflict resolution and communication skills training in educational institutions. Ogelman et al. [10], teachers need to closely follow the dynamics of children's peer relations, observe peer choices, conflict situation and the consequences of conflicts. Teachers should establish a culture of peace in schools and present themselves as role models of peace. They must resolve any problems and conflicts among themselves and among students through dialogue [11]. Kutlu and Bedel [3] found that the conflict resolution psycho-education program applied to adolescents increased their integration and compliance scores. Conflict resolution strategies can create a positive environment for the psychological well-being of adolescents who are victims [12]. In resolving conflicts, those who recognize and notice their emotions make an effort to show appropriate behavior for each emotion [13].

Conflicts typically focus on conflicts over authority, autonomy, responsibilities, and appropriate behavior [14]. According to Demir, and Dilmaç [15], conflict is addressed as interpersonal problem, and conflict resolution as interpersonal problem solving ability. People spend a significant portion of their time and energy on processes such as problem solving and decision making [16]. Conflict resolution strategy can generally be defined as the way the individual copes with interpersonal conflict [17]. Keçicioğlu [18] defines conflict as a conflict between two or more parties that are in relation with each other, as a result of scarce resources and the mismatch of needs and interests. Showing negative behaviour students who create more conflict situations and exhibit violent behavior in schools [19]. Koruklu and Yilmaz [20] stated that the conflict resolution process started when the opponents were able to communicate their problems to each other by communicating in a conciliatory manner without blaming the other opponent.

Turk [21] conflict resolution, peace education and peer mediation training programs have a wide impact on the conflict resolution skills of others. Ateş [22] found that as a result of the conflict resolution training program, the conflict resolution skills and self-esteem levels of the students in the experimental group increased. Serin et al. [23] found that gifted students use constructive and positive conflict resolution strategies to resolve conflicts. Boele et al. [24] found that males have higher mean aggression scores than females, and females have higher mean scores for constructive problem solving than males. It was found that the male students used aggressive behavior more [25]. Bedel and Güler [26] found that there was no significant difference between male and female students in the mean scores of Coping Strategies, Bullying and Aggression Scale, according to the results of the study. Johnson and Johnson [27] in their study, they state that it would be more effective for them to participate in peer mediation practices in schools. Students should be informed and supported by school psychological counselors and school administrators in order for secondary school students to get to know themselves better and to develop themselves in a quality that will contribute to the society [28].

This study is important in terms of reducing the violent tendencies of adolescents studying at the secondary school level, adopting a constructive and healthy attitude in the conflicts they experience, developing peaceful friendship relations, and providing students with skills that will contribute to their social and emotional development. School atmosphere is a place where interpersonal communication is too intense. Since the life and personal characteristics of students who share this atmosphere are different from each other, it is inevitable that the interaction between individuals turns into conflict over time. It is necessary to investigate the causes of aggression and violent behaviors experienced in schools in recent years and the ways to reduce such behaviors. Conflicts are an inevitable part of school life as in every sphere of life, and aggressive behavior emerges as a tool used to resolve conflict when there is a conflict about students' interests, values, and needs. Minimizing the negative effects of conflicts and trying to develop constructive conflict resolution skills will make a positive contribution to human relations.

Examining the relevant literature reveals that there are relatively few studies examining the conflict resolution behaviors of young people attending secondary schools in Northern Cyprus, a country with diverse cultures. More research is needed to prevent violence and aggression, protect young people's mental health, and reduce interpersonal conflicts in secondary schools with students from diverse cultural backgrounds. This study's findings on the conflict resolution behaviors of secondary school students in Northern Cyprus are significant in terms of reducing young people's conflict behaviors, utilizing them constructively and peacefully in the conflicts they encounter, and protecting their social, emotional, and mental health.

To help avoid aggression and violence in the school setting, identify the variables that influence the situations in which adolescents encounter conflict, their behavioral patterns and reporting in conflict situations, and their conflict resolution behaviors. Furthermore, schools are places where students learn skills that will help them grow. When school-based psychological counseling and guidance activities are planned, this information is thought to be necessary.

Int. J. Public Health Sci., Vol. 10, No. 4, December 2021 : 865 - 872 
- The aim of research

The purpose of this study was to examine whether there are significant differences between the conflict resolution behaviors of the students studying in secondary schools in the Northern Cyprus and some socio-demographic variables. For this purpose, answers to the following questions were sought. In the conflict resolution behaviors of middle school students; gender, grade level; their age; the education level of the mother and father; comitative of mother and father; is there a significant difference according to the number of siblings and their success?

\section{RESEARCH METHOD}

This research examined the conflict resolution behaviors of students studying at three state secondary schools affiliated to the Northern Cyprus Ministry of National Education in terms of different socio-economic variables. It was a descriptive study prepared using a quantitative research method that examined the conflict resolution behaviors of middle school students. This model was a method of empirical analysis used to evaluate the interactions between more than one component. It examined the interaction between variables.

\subsection{Population and sample}

The universe of this research was composed of students studying in secondary schools in the district center of Famagusta in the Northern Cyprus. The sample of this research was students attending public secondary schools in Famagusta district of the Northern Cyprus. The study was conducted with a total of 175 students, 76 girls (43.3\%) and 99 boys (56.5\%). The sample of the study consisted of the students who meet from the students studying in three secondary schools. The required sampling procedure, one of the nonrandom sampling techniques, was used to determine the test sample.

\subsection{Data collection tools}

The Scale of Determining Conflict Resolution Behavior, developed by Koruklu [29], was used in the study to collect data. Koruklu [29], the approaches that constitute the theoretical background in the study of developing the "Scale for Determining Conflict Resolution", competitive and collaborative approach; three-dimensional approach based on solution-oriented, domination and avoidance and approaches that deal with interpersonal conflicts with two basic orientations has been utilized. The Scale for Determining Conflict Resolution Behavior is a five-point Likert type scale consisting of 24 items. Reliability studies of the scale were evaluated by the test-retest technique by Koruklu [29]. According to the results of the test-retest applications, a reliability coefficient of .66 was obtained for problem solving in the Conflict Resolution Behavior Determination Scale. The internal consistency coefficients of the Scale for Determining Conflict Resolution Behavior were determined as $\mathrm{r}=.83$ for the problem-solving dimension. Both content and construct validity were investigated for the scale's validity study. An expert opinion was obtained to ensure the validity of the content. The construct validity of the scale was determined using factor analysis. Each item's load value with its own factor was determined to be greater than .40 . Item analysis was used to determine how distinct the items were in terms of conflict resolution behavior. When the item-total correlations for 24 items were examined, they were all found to be higher than .30. A high score suggests that the behavior is common.

The Conflict Resolution Behavior Scale includes items measuring conflict resolution behaviors. Example scale items: "I am offended when a classmate does not invite me to his birthday party.", "If they excluded me from the debate groups formed during the Turkish lesson, I would inquire as to why and express my desire to participate.", and "If friends attend a classroom party without informing me, I interrogate and speak with them about it."

\subsection{Data analysis and application}

For the purposes of the study in the analysis of the data; Percentage breakdown, one-way analysis of variance (ANOVA), t-test techniques were used. The significance level was taken as .05 in the study. Before using the Data Collection Tools, the students were informed that these Data Collection Tools included volunteering. All of the students in all classes where the application was made declared their voluntariness. Then, the students were demonstrated on how to use and answer the Data Collection Tools. It took approximately 20 minutes for students to use and answer the Data Collection Tools. A total of 210 secondary school students participated. In the end, 35 of the Data Collection Tools were excluded from the study due to the answers being left blank around $10 \%$ or more in each tool. 


\section{RESULTS}

The findings obtained for the questions determined in line with the purpose of this research are presented below. As seen in Table 1, the mean score of the male students on the conflict resolution scale was found to be 85.64, while the average score of the female students was 89.03. There was no significant difference between these two averages ( $p>.05$ ). In Table 2, no significant difference was found between the conflict resolution behaviors of the students and their grade level scores in terms of conflict resolution.

Table 1. Conflict resolution behavior score average analysis of participants according to gender

\begin{tabular}{lccccccc}
\hline Gender & $\mathrm{n}$ & Mean & Std.Dev. & df & $\mathrm{t}$ & $\mathrm{p}$ & Significance level \\
\hline Male & 99 & 85.64 & 16.278 & \multirow{2}{*}{173} & .730 & .198 & $\mathrm{p}>.05$ \\
Female & 76 & 89.03 & 18.311 & & & & \\
\hline
\end{tabular}

Table 2. Conflict resolution behavior score average of participants by grade levels ANOVA results

\begin{tabular}{lcccccc}
\hline & Sum of squares & df & Mean of squares & F & p & Significance level \\
\hline Between groups & 763.701 & 2 & 381.851 & & & \multirow{2}{*}{$>05$} \\
In groups & 50847.236 & 172 & 295.623 & 1.292 & .277 & p \\
Total & 51610.937 & 174 & & & & \\
\hline
\end{tabular}

In Table 3, the difference between the mean scores for conflict solving behaviors of the students according to their ages was found to be significant $\left(\mathrm{F}_{(4.170)}=2.596, \mathrm{p}<.05\right)$. Accordingly, the age that students had the best score in terms of conflict resolution behaviors was found to be 15; a significant difference was found between the ages of 15 and especially between the ages of 12-13 in terms of conflict resolution behaviors. As seen in Table 4, the mean score of the students whose parents are together on the conflict resolution scale was found to be 88.29 , while the average of the students whose parents were separate was $81.14[\mathrm{t}=2.063, \mathrm{p}<.05]$. It can be said that students whose mothers and fathers are together are more prone to conflict resolution than students whose parents are not together. As seen in Table 5, a significant difference was found between the average scores of conflict solving behaviours according to the number of siblings of the students $\left(\mathrm{F}_{(4.170)}=5.704, \mathrm{p}<.05\right)$. It was found that the mean scores of conflict resolution behaviours of students in families with children were significantly higher.

Table 3. The average conflict resolution behaviour score of the participants by age ANOVA analysis

\begin{tabular}{lcccccc}
\hline & Sum of squares & df & Mean of squares & F & p & Significance level \\
\hline Between groups & 2970.701 & 4 & 742.675 & & & \\
In groups & 48640.236 & 170 & 286.119 & 2.596 & $.038^{*}$ & $\mathrm{p}<.05$ \\
Total & 51610.937 & 174 & & & & \\
\hline
\end{tabular}

Table 4. Conflict resolution behavior scores of the participants according to their parent association status ANOVA analysis

\begin{tabular}{lccccccc}
\hline Mother father togetherness & $\mathrm{n}$ & Mean & Std.Dev. & $\mathrm{df}$ & $\mathrm{t}$ & $\mathrm{p}$ & Significance level \\
\hline Divorce & 29 & 81.14 & 20.436 & \multirow{2}{*}{173} & \multirow{2}{*}{2.063} & \multirow{2}{*}{$.041^{*}$} & $\mathrm{p}<.05$ \\
Together & 146 & 88.29 & 16.332 & & & & \\
\hline
\end{tabular}

Table 5. Conflict resolution behaviour score average ANOVA analysis according to number of siblings of participants

\begin{tabular}{lcccccc}
\hline & Sum of squares & $\mathrm{df}$ & Mean of squares & $\mathrm{F}$ & $\mathrm{p}$ & Significance level \\
\hline Between group & 6106.960 & 4 & 1526.740 & & & \\
In group & 45503.977 & 170 & 267.670 & 5.704 & $.000^{*}$ & $\mathrm{p}<.05$ \\
Total & 51610.937 & 174 & & & & \\
\hline
\end{tabular}

As seen in Table 6, a significant difference was found between the average scores of the conflict solving behaviours of the students according to their success level in the lessons $\left(\mathrm{F}_{(3,171)}=5.925, \mathrm{p}<.05\right)$. According to the results of the Scheffe test, it was found that the average scores of the conflict resolution behaviours of the students who stated their achievement level as "very good" in the lessons were significantly higher than the students who stated the success level as "very bad" and "slightly bad" in the lessons. 
Table 6. Conflict resolution behaviour score average of participants according to perceived course success level ANOVA analysis

\begin{tabular}{lcccccc}
\hline & Sum of squares & sd & Mean of squares & F & $\mathrm{p}$ & Significance level \\
\hline Between group & 4859.702 & 3 & 1619.901 & & & \\
In group & 46751.235 & 171 & 273.399 & 5.925 & $.001 *$ & $\mathrm{p}<.05$ \\
Total & 51610.937 & 174 & & & & \\
\hline
\end{tabular}

\section{DISCUSSION}

When the findings of this study were evaluated in general, it was revealed that conflict resolution behaviors did not differ between males and females. In Mutluoğlu [30], Mutluoğlu and Serin [31] studies, a significant difference was found in conflict resolution abilities by gender, except for one dimension. Sevgi and Karakaya [32], a significant difference was found between the scores of the Conflict Resolution Behavior Scale Aggression Sub-Dimension of female and male students. According to the results of the research conducted by Erdoğan [33], it was revealed that male students used more aggressive strategies in solving their conflicts related to physical violence. In the study conducted by Semra and Demir [34], it was determined that male students behaved more aggressively than female students. It is seen that male's aggression scores are higher than females. Yavuzer et al. [35], Girgin and Özçelik [36], show that females scores are higher than males in terms of conflict resolution problem solving scores. Arslan, Hamarta, Arslan, and Saygin [37] found that men mostly resort to aggressive behaviors in conflict resulations. In their study with university students, it was found that gender has no effect on conflict resolution [38]. In this study, there was no significantly difference in conflict resolution behavior between genders. The reasons for this can be explained by the multicultural structure of Northern Cyprus, the fact that both genders prefer peaceful behavior over aggression, and the fact that girls are raised with a self-confident and self-confident attitude.

In this study, no significant difference was found between the conflict resolution behaviors of the students according to their grade levels. Sevgi and Karakaya [32] reached a conclusion similar to the results of this study that there was no difference in terms of the grade level at which students continue in problem solving in their study of $6^{\text {th }}, 7^{\text {th }}$ and $8^{\text {th }}$ grades. In some studies, in which aggression is associated with grade level, it was found that students who continue their education in general secondary school [39] and students who are in their last year [25] resort to aggressive behavior more. Yavuzer, Karataş and Gündoğdu [35] found that males, $10^{\text {th }}$ and $11^{\text {th }}$ grade students resorted to aggression, females and $9^{\text {th }}$ graders in conflict situations.

The age at which the students had the best score in terms of conflict resolution behaviors was found to be 15; As a result, a significant difference in conflict resolution behavior between the ages of 15 and especially between the ages of 12-13 developed. The findings of Tuzcuoğlu and Erdoğan [40], in their study with the 11-12 age group, that there is no significant difference between the education level of mothers and the conflict resolution behavior of children supports that study. The tendency to intervene in social conflicts between secondary schools, especially when the conflicts it involves become severe [41]. Taylor [42] found that the psychoticism level of the 15-19 age group is higher than the other age groups. Ar1 and Yaban [43], it is emphasized that having siblings has a positive effect in the management of peer conflicts. This finding can be explained by the fact that as adolescents progress through adolescence, more peaceful and positive problem-solving behaviors tend to increase rather than aggressive behaviors.

In this study, the conflict resolution behavior scores of the students whose parents were together were found to be significantly higher than the students whose parents were divorced. This situation shows that students whose parents are divorced more prone to conflict. The quality of Children's Perception of Inter-parental Conflict on bullying was studied, and it was found that adolescents generally thought like their parents even if they have conflicts with them [44].

One of the results of this study is that students with high levels of success are significantly higher in conflict resolution behaviors than students with low success levels.Students with high levels of success are significantly higher in conflict resolution behaviors than students with low achievement levels. It was found that there was no significant difference in the conflict resolution skills relationship according to the income level of the parents. It was found that the mean scores of conflict resolution behaviors of students with only one child were significantly higher than students in families with 3-4 children. As a result, it has been revealed that students whose parents are together are more predisposed to conflict resolution than students whose parents are not together. Girgin and Özçelik [36], in their studies, a significant difference was found according to the academic success of the students. 


\section{CONCLUSION}

In general, when the results of the study are examined, it has been revealed that conflict resolution behaviors do not differ between males and females. In this study, the conflict resolution behaviour scores of the students whose parents were together were found to be significantly higher than the students whose parents were divorced. This situation shows that students whose parents are divorced are more prone to conflict. It has been found that conflict resolution behaviours, the grade levels of the students and. The age at which the students had the best score in terms of conflict resolution behaviours was found to be 15 . As a result, a significant difference in conflict resolution behaviour between the ages of 15 and especially between the ages of 12-13 emerged. Consequently, it is an indicator that conflict resolution abilities improve as students get older. Students with high levels of success are significantly higher in conflict resolution behaviours than students with low achievement levels. The fact that school guidance services are in constant communication with low achieving students can help these students to know themselves and have selfconfidence, as well as contribute to learning conflict resolution abilities.

This study was conducted with secondary school students in Famagusta district in the Northern Cyprus, so the generalization of the findings of study is limited with this sample group. In new studies about this subject, it may be suggested to work with students of different levels, different variables, and different age groups. Studies can be conducted to examine conflict resolution behaviors in private schools. There are many research findings that indicate that there is no significant difference in the conflict resolution skills of secondary school students according to the education levels of their mothers and fathers. Studies can be conducted to understand the reasons for this quite interesting situation. It is recommended that similar studies with adolescents employ qualitative methods in addition to quantitative measurements to examine conflict resolution behaviors and to conduct in-depth interviews with adolescents to discuss conflict resolution behaviors in detail.

\section{ACKNOWLEDGEMENTS}

This article is based on a master's thesis conducted under the direction of the second author by the first author in the area of Guidance and Psychological Counselling at the European University of Lefke Institute of Graduate Studies and Research.

\section{REFERENCES}

[1] M. Larusso, and R. Selman, "Early adolescent health risk behaviors, conflict resolution strategies, and school climate," Journal of Applied Developmental Psychology, vol. 32, no. 6, pp. 354-362, 2011, doi: 10.1016/j.appdev.2011.05.003.

[2] H. Bonache, R. Gonzalez-Mendez, and B. Krahé, "Adult attachment styles, destructive conflict resolution, and the experience of intimate partner violence," Journal of Interpersonal Violence, vol. 34, no. 2, 287-309, 2019, doi: $10.1177 / 0886260516640776$

[3] A. Kutlu, and A. Bedel, "Çatışma çözme programının ortaokul öğrencilerinin çatışma çözüm becerilerine, sürekli öfke ve öfke ifade tarzlarına etkisi (In English: The effect of conflict resolution program on middle school students' conflict resolution skills, trait anger and anger expression styles)," Elementary Education Online, vol. 18, no. 1, pp. 97-111. 2019, doi: 10.17051/ilkonline.2019.527165.

[4] S. W. Smith, A. P. Daunic, M. D. Miller, and T. R. Robinson, "Conflict resolution and peer mediation in middle schools: Extending the process and outcome knowledge base," The Journal of social psychology, vol. 142, no. 5, pp. 567-586, 2002, doi: 10.1080/00224540209603919

[5] F. Demir, "Ortaokullarda öğrencilerin disiplinsiz davranışları ve bu davranışların sebepleri (Batman ili merkez ilçesi örneği) (In English: The students undescribed behaviorus and causes of this behaviors in the secondary schools (Batman province central district example)," Unpublished Master's Thesis, İnönü University, Malatya, 2013.

[6] K. A. Davis, and V. A. Mccoy, "Strategies for conflict resolution among middle school students," VISTAS, vol. 4, no. 4, pp.1-9. 2016.

[7] N. Shahmohammadi, "Conflict management among secondary school students," Procedia-Social and Behavioral Sciences, vol. 159, 2014, pp. 630-635, doi: 10.1016/j.sbspro.2014.12.438.

[8] S. V. Sandy, and K. M. Cochran, "The development of conflict resolution skills in children: Preschool to adolescence," In M. Deutsch and P. T. Coleman (Eds.), the handbook of conflict resolution: Theory and practice (pp. 316-342). Jossey-Bass/Wiley, 2000.

[9] N, Koruklu, "Eğitimde arabuluculuk ve okulda arabuluculuk sürecinin işleyişine ilişkin bir model (In English: A model for the functioning of mediation in education and mediation in school)," Buca Faculty of Education Journal, no. 20, pp. 11-20, 2006.

[10] H. Gülay Ogelman, İ. Göktaş, and P. Aytaç, "The reasons for young children to like and dislike playing with their friends,” International Online Journal of Primary Education, vol. 9, no. 2, pp. 316-326, 2020. 
[11] L. Mishra, T. Gupta, and A. Shree, "Guiding principles and practices of peace education followed in secondary schools of Mizoram," International Journal of Evaluation and Research in Education (IJERE), vol. 9, no. 4, pp. 1096-1101, 2020, doi: 10.11591/ijere.v9i4.20738.

[12] B. Marroquín, and S. Nolen-Hoeksema, "Emotion regulation and depressive symptoms: Close relationships as social context and influence," Journal of Personality and Social Psychology, vol. 109, no. 5, pp. 836-855, 2015, doi: $10.1037 / \mathrm{pspi0000034}$

[13] E. Gürsoy, and S. B., Çelik, "Duygusal zeka beceri eğitiminin ergenlerde duygusal zeka, empatik beceri ve davraniş problemleri üzerine etkisi (In English: The Effects of Emotional Intelligence Skill Education on Emotional Intelligence, Empathic Skill and Behavior Problems of Teenagers)," Journal of Kırşehir Education Faculty, vol. 21, no. 1, pp. 303-327, 2020.

[14] J. G. Smetana, “Adolescents' social reasoning and relationships with parents: Conflicts and coordinations within and across domains, " London: Cambridge University Press, pp.139-158, 2011.

[15] S. Demir, and B. Dilmaç, "Ergenlerin kişilerarası problem çözme becerileri ve empatik eğilimlerinin sahip oldukları değerler açısından incelenmesi (In English: Analysis of Interpersonal Problem Solving Skills and Empathic Tendencies of Adolescents)," OPUS International Journal of Society Researches, vol. 11, no. 18, pp. 134-156, 2019

[16] A. Bedel and B. Özdemir, "Ortaokul öğrencilerinin problem çözme becerilerinde otomatik düşüncelerinin ve karar verme stillerinin rolü (In English: The role of automatic thought and decision-making styles in middle school students' problem-solving skills)," Marmara University Atatürk Education Faculty Journal of Educational Sciences, vol. 53, no. 53, 309-325, 2019.

[17] T. Kim-Jo, V. Benet-Martínez, and D. J. Ozer, "Culture and interpersonal conflict resolution styles: Role of acculturation. Journal of Cross-Cultural Psychology, vol. 41, no. 2, pp. 264-269, 2010, doi: $10.1177 / 0022022109354643$.

[18] Y. Keçicioğlu, "Sosyal bilgiler öğretmenlerinin empatik eğilim düzeyleri ile çatışma çözme becerilerinin incelenmesi (Bursa ili örneği) (In English: Examination of social studies teachers' empathic tendency levels and conflict resolution skills (Bursa example))." Unpublished Master's thesis, Bursa Uludağ University, Bursa, 2020

[19] S. Kilıçarslan and M. Atıcı, "Çatişma çözme eğitim programinin ilköğretim 6. ve 7. sinif öğrencilerinin çatişma çözme davranişlari üzerindeki etkisi (In English: The effects of conflict resolution training program on conflict resolution behaviour of 6th and 7th grade)," Journal of Çukurova University Institude of Social Sciences, vol. 24, no. 2, pp. 137-158, 2015.

[20] N. Koruklu, and N. Yilmaz, "Çatışma çözme ve arabuluculuk eğitimi programının okulöncesi kurumlara devam eden çocukların problem çözme becerisine etkisi (In English: The effect of conflict resolution and mediation education on problem solving behavior of 6 years old children)," Adnan Menderes Üniversitesi Eğitim Fakültesi Ë̆itim Bilimleri Dergisi, vol. 1, no. 1, pp. 1-20, 2010.

[21] F. Turk, "Evaluation of the effects of conflict resolution, peace education and peer mediation: A meta-analysis study," International Education Studies, vol. 11, no. 1, pp. 25-43, 2018, doi: 10.5539/ies.v11n1p25.

[22] N. Ateş, "Çatışma çözme eğitiminin 6.sinıf öğrencilerinin çatışma çözme becerileri ve özsaygı düzeylerine etkisi (In English: The aim of this study is to examine the effectiveness of the conflict resolution education programme on the conflict resolution skills and self esteem of 6 grade students)," Unpublished Master's Thesis, Haliç University, İstanbul, 2014.

[23] O. Serin, N. B. Serin, and G. Saygil1, "The conflicts that exceptionally gifted students encounter and their opinions, observations and experiences regarding the solutions of these conflicts," The Anthropologist, vol. 23, no. 1-2, pp. 185-193, 2016, doi: 10.1080/09720073.2016.11891940.

[24] S. Boele, J. Van derGraaff, M. De Wied, I. E. Van der Valk, E. Crocetti and S. Branje, "Linking parent-child and peer relationship quality to empathy in adolescence: A multilevel meta-analysis," Journal of youth and adolescence, vol. 48, no. 6, pp. 1033-1055, 2019, doi: 10.1007/s10964-019-00993-5.

[25] A. Hanani, and M. Piskin, "Gender difference and bullying among secondary school students in Palestine," Open Journal of Depression, vol. 9, no. 4, pp. 95-100, 2020, doi: 10.4236/ojd.2020.94009.

[26] A. Bedel and G. Güler, "Ortaokul öğrencilerinde zorbalığı ve saldırganlığı açıklamada başa çıkma stratejilerinin rolü (In English: The role of coping strategies in explaining middle school students' bullying and agression)," Electronic Journal of Social Sciences, vol. 19, no. 73, pp. 105-121, 2020, doi: 10.17755/esosder.447474

[27] W. D. Johnson and R. Johnson, "Teaching students to be peacemakers: A meta-analysis," Research Reports. The Annual Meeting of the American Educational Research Association (Seattle WA. 10-14 April 2001). [Online]. Available: https://files.eric.ed.gov/fulltext/ED460178.pdf

[28] S. Aktaş, İ. Aktaş, and S. Kalaycı, "Duygusal zeka, bilimsel süreç becerileri ve fen başarısı arasındaki ilişki (In Englsh: The relationship between emotional intelligence, scientific process skills and science achievements)," International Journal of New Trends in Arts, Sports \& Science Education, vol. 9, no. 4, pp. 166$177,2020$.

[29] N. Koruklu, "A study on developing the revised version of the "conflict resolution behavior determination scale" (CRBDS)," International Journal of Psycho-Educational Sciences, vol. 7, no.1, pp. 142-155, 2018.

[30] S. Mutluoğlu, "6. Sınıf öğrencilerinin bazı değişkenlere göre çatışma çözme davranışlarının incelenmesi (In English: study of some of the changes occording to solving the conflict of first year secondary school students]," Turkish International Journal of Special Education and Guidance \& Counselling, vol. 4, no. 1, pp. 16-26, 2015.

[31] S. Mutluoğlu, and O., Serin, "Çatıșma çözme eğitim programının ilkokul 5. sınıf öğrencilerinin çatıșma çözme becerilerine etkisi (In English: A programme of solving conflict within education in $5^{\text {th }}$ year primary school 
children the skills of the effects of solving conflict solving the conflict of first year secondary school students)," Turkish International Journal of Special Education and Guidance \& Counselling, vol. 1, no. 1, pp. 44-52, 2012.

[32] S. Sevgi, and M. Karakaya, "Investigation of metacognition awareness levels and problem solving skills of middle school students," International Online Journal of Primary Education, vol. 9, no. 2, pp. 260-270, 2020.

[33] F. H. Erdoğan, "Ortaokula devam eden 11-12 yaş grubu çocukların çatışma çözme davranışları ile annelerinin ebeveyn tutumları arasindaki ilişkinin incelenmesi (In English: Examining the relationship between conflict resolution behavior of children at secondary school aged 11-12 with parental attitudes of mothers)," Unpublished Master's Thesis, Marmara University, İstanbul, 2014.

[34] İ. Y. E. Semra, and E. Demir, "7. Sınıf öğrencileri düzeyinde duygusal zekâ ile çatışma çözme davranış1 arasındaki ilişkinin bazı değişkenlere göre incelenmesi (In English: Examining the relationship between emotional intelligence and conflict resolution behavior of the 7th grade students according to some variables)," Journal of Social Sciences of Mus Alparslan University, vol. 6, no. 5, pp. 639-645, 2018, doi: 10.18506/anemon.382322.

[35] Y. Yavuzer, Z. Karataş, and R. Gündoğdu, "Ergenlerin çatışma çözme davranışlarının incelenmesi: nicel ve nitel bir çalışma (In English: An investigation of conflict resolution behaviours: A quantitative and qualitative study)," Hacettepe University Journal of Education, vol. 28, no. 28-1, pp. 428-440, 2013.

[36] Ü. Girgin, and A. D. Özçelik, "Meslek lisesi öğrencilerinin çatışma nedenleri (In English: Reasons for conflicts between students of vocational high schools)," Ulakbilge, vol. 8, no. 50, pp. 723-741, 2020, doi: 10.7816/ulakbilge-08-50-01.

[37] C. Arslan, E. Hamarta, E. Arslan, and Y. Saygın, "An investigation of aggression and interpersonal problem solving in adolescents," Elementary Education Online, vol. 9, no. 1, pp. 379-388, 2010.

[38] N. Akhtar, and S. Javed, "Conflict management styles of students with teachers; a study of universties in lahore Pakistan,” Journal of Empirical Economics and Social Sciences, vol. 1, no. 1, pp. 29-39, 2019.

[39] M. Melikoğlu, "Ortaokul öğrencilerinin problem çözme becerileri ile sosyal uyum becerileri ve sosyal duygusal öğrenme becerileri arasındaki ilişkinin incelenmesi (In English: Investigation of the relationship between problem solving skills and social adaptation skills and social emotional learning skills of secondary school students)," Unpublished Master's Thesis, Maltepe University, İstanbul, 2020.

[40] S. Tuzcuoğlu and F. H. Erdoğan, "Ortaokula devam eden 11-12 yaş grubu çocukların çatışma çözme davranışları ile annelerinin ebeveyn tutumları arasındaki ilişkinin incelenmesi (In English: Examining the relationship between conflict resolution behavior of children at secondary school aged 11-12 with parental attitudes of mothers)," The Journal of Academic Social Sciences, vol. 2, no. 8, pp. 355-369, 2014.

[41] S. H. Gwon, and C. Y. Lee, "Factors that influence sexual intercourse among middle school students: using data from the 8th (2012) Korea Youth Risk Behavior Web-based Survey," Journal of Korean Academy of Nursing, vol. 45, no. 1 , pp. 76-83, 2015.

[42] J. L. Taylor, "Interventions for violent offenders with intellectual and developmental disabilities," The Wiley Handbook of What Works in Violence Risk Management: Theory, Research and Practice," Book Editor(s): J. Stephen Wormith, Leam A. Craig, Todd E. Hogue. pp. 451-464, 2020, doi: 10.1002/9781119315933.ch23.

[43] M. Arı and H. Yaban, "9-11 yaşındaki çocukların sosyal problem çözme becerilerinde cinsiyet ve yaş farklılıkları [Age and Gender Differences in Social Problem Solving Skills of 9-11 year-old children]," Education and Sclence, vol. 37 , no. 164, pp. 188-203, 2012.

[44] A. Ateş, "Perception of peer bullying and victimization amoung early adolescent," International Online Journal of Primary Education, vol. 6, no. 1, pp. 50-58, 2017. 